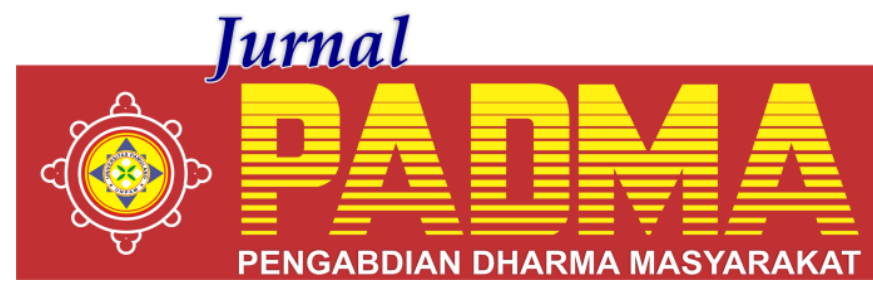

VOLUME 1, NOMOR I, JANUARI 2021

\title{
MEMPERKUAT MOTIVASI BELAJAR DENGAN PENYUSUNAN RENCANA KARIR SMK SASMITA
}

\author{
${ }^{1 *}$ Abdul Khoir, ${ }^{2}$ Janudin, ${ }^{3}$ Reza Octovian, ${ }^{4}$ Widia Astuti, 5 Theobaldus Boro Tura \\ Universitas Pamulang, Tangerang Selatan, Banten, Indonesia \\ *dosen02490@unpam.ac.id
}

\begin{abstract}
Abstrak
Apabila dicermati, maka permasalahan yang dihadapi siswa sebagian besar sama, antara lain: (a) siswa pada umumnya tidak paham dengan potensinya sendiri, sehingga ragu-ragu dalam menentukan penjurusan atau bidang studi di perguruan tinggi yang diinginkan, (b) kurang mengetahui cara memilih program studi, (c) wawasan dan pemahaman siswa mengenai jurusan yang ada di sekolah dan di perguruan tinggi (d) siswa belum mempunyai perencanaan yang matang mengenai pendidikan maupun pekerjaan yang akan dipilih nanti. Permasalahan kematangan karir merupakan permasalahan masa depan remaja sehingga harus dipersiapkan dengan sebaik baiknya, seperti dalam hal merencanakan dan mengambil suatu keputusan karir
\end{abstract}

Kata Kunci : Motivasi Belajar, Rencana Karir

\section{Abstract}

The purpose of this activity is to foster the spirit of young entrepreneurs is needed in accordance When examined, the problems faced by students are mostly the same, among others: (a) students in general do not understand their own potential, so they are hesitant in determining majors or fields of study in the desired tertiary institution, (b) lacking in knowing how to choose programs studies, (c) students' insights and understanding of the majors in school and in tertiary institutions (d) students do not yet have a careful planning regarding education or work to be chosen later. The problem of career maturity is a problem of the future of adolescents so it must be well prepared, as in the case of planning and making a career decision

Keywords: Learning Motivation, Career Plan

\section{PENDAHULUAN}

Siswa dalam jenjang SMA dan SMK dalam hal ini remaja sering kali tidak dengan mudah menyelesaikan tugas perkembangan karirnya. Siswa seringkali mempunyai permasalahan yang berhubungan dengan kelanjutan studi atau pekerjaan setelah lulus. Hal ini sesuai dengan pendapat Supriatna (2009:23) masalah-masalah yang sering muncul diantaranya kebingungan dalam memilih program studi, memilih jurusan di perguruan tinggi, menentukan cita-cita atau bahkan tidak memahami bakat dan minat yang dimiliki, dan merasa cemas untuk mendapat pekerjaan setelah tamat sekolah. Kebingungan yang sering dialami siswa diantaranya pada saat mereka akan memilih jurusan di kelas XI ataupun memutuskan pilihan pendidikan setelah lulus SMA, ditambah adanya perasaan cemas dalam menghadapi masa depan dan dunia kerja.
Selain itu, fenomena yang sering muncul sampai saat ini bahwadalam menentukan pilihan karirnya siswa SMA masih sering mengikuti teman atau orang tua. Kondisi ini diperkuat oleh pendapat Darajat (Rauf, 2006:7) yang mengemukakan bahwa:

Tidak jarang kita mendengar remaja mengeluh bahwa hari depannya suram, tidak jelas, di mana akan bekerja, profesi apayang cocok baginya dan sebagainya. Akan tetapi di lain pihak ia tidak melihat jalan untuk menghadapinya, kerena kenyataan hidup dalam masyarakat yang tidak memberikan kepastian kepadanya. Hal ini erat hubungannya dengan macam dan jenis sekolah serta jenis serta sistem pendidikan yang dilaluinya. Oleh karena itu permasalahan karir yang telah dikemukakan harus segera dicari jalan keluarnya, jika hal ini dibiarkan tanpa ada 
upaya untuk mencari jalan keluarnya maka siswa tidak akan memiliki perencanaan dan pengambilan keputusan yang matang. Hal tersebut senada dengan pendapat Santrock (1996: 484) bahwa salah satu hal yang berperan penting dalam pemilihan karir remaja yaitu perencanaan dan pengambilan keputusan.

Identifikasi masalah di lapangan menunjukkan masih banyak siswa yang belum memiliki planning dan rencana untuk melangkah di tahap selanjutnya,. Mereka cenderung apatis dengan keadaan yang ada sehingga dikhawatirkan hal tersebut dapat berimbas pada motivasi belajar, hasil belajar, serta pencapaian mereka di masa yang akan datang.

Pengabdian kepada masyarakat merupakan pelaksanaan pengamalan ilmu pengetahuan, teknologi dan seni budaya langsung pada masyarakat secara kelembagaan melalui metodologi ilmiah sebagai penyebaran Tri Dharma Perguruan Tinggi serta tanggung jawab yang luhur dalam usaha mengembangkan kemampuan masyarakat, sehingga dapat mempercepat laju pertumbuhan tercapainya tujuan pembangunan nasional.

Siswa SMK Sasmita memiliki permasalahan untuk menentukan karir mereka selanjutnya. Beberapa Siswa SMK Sasmita masih belum mengatahui rencana kedepan yang harus diambil. Hal itu dikarenakan mayoritas dari siswa tersebut tidak memiliki kecakapan yang cukup dalam menyusun rencana karir untuk masa depannya. Sebagai salah satu SMA Unggulan di Tangerang Selatan, SMK Sasmita berkewajiban membentuk mindset dan ketrampilan peserta didiknya agar mampu bersaing di era milenial saat ini. Salah satunya adalah dengan memberikan workshop mengenai pentingnya rencana karir serta strategi bersaing di era milenial. Agar Siswa dapat memiliki semangat dalam belajar yang terstruktur sejak dini, mampu memetakan diri dan dapat membuat branding diri untuk meraih cita-cita.

Adapun tujuan dari kegiatan pengabdian kepada masyarakat ini adalah untuk memberikan workshop siswa SMK Sasmita memahami dan mampu menyusun renca karir untuk masa depan mereka selanjutnya. Penyusunan rencana karir yang benar akan mampu memberikan pemantapan dan fokus siswa dalam merah cita-cita. Sehingga diharapkan akan mengurangi ketidakmautahuan siswa dalam menyusun rencana di masa yang akan datang.

Kegiatan pengabdian kepada masyarakat dari tim dosen dan mahasiswa Universitas Pamulang hadir di SMK Sasmita, serta berbagi pengetahuan dan wawasan dengan bentuk workshop menyusun rencana karir untuk memperkuat motivasi belajar siswa. Workshop yang bertujuan menumbuhkan kepercayaan diri dalam diri mahasiswa ini semata-mata untuk membangun mental positif dan optimism tentang karirnya di masa depan, yang tentunya akan menjadi modal yang kuat dalam mencapai cita-cita di masa yang akan datang.

Tim pengusul pengabdian kepada masyarakat berharap respon dan antusiasme, khususnya siswa SMK Sasmita dalam memperkuat motivas belajar dengan menyusun rencana karir. Sehingga kegiatan pengabdian kepada masyarakat tidak hanya berhenti pada kegiatan workshop ini tetapi dapat berkelanjutan sesuai kebutuhan siswa, terutama yang berkaitan dengan pengembangan karakter sebagai bentuk kepedulian terhadap diri sendiri dan rencana karirnya di masa depan.

Sasaran kegiatan Pengabdian kepada masyarakat (PKM) ini adalah dengan merangkul siswa SMK SASMITA untuk mengikuti kegiatan meningkatkan softskill dengan tema "Memperkuat motivasi belajar dengan penyusunan rencana karir SMK Sasmita".

\section{METODE}

Dalam kegiatan ini metode yang diterapkan diharapkan dapat memberikan kemudahan kepada para mahasiswa SMK Sasmita. Metode yang digunakan adalah metode diskusi kelompok, sharing, tanyajawab, praktik yang di damping oleh co trainer. Pada metode penjelasan, setiap instruktur menyampaikan materi terkait dan membuat tampilan visual berupa slide power point yang ditampilkan ke layar dengan LCD proyektor.

Instruktur dalam menyampaikan penjelasan juga memasukkan unsur 
"sharing" atau berbagi pengalaman mengenai penggunaan rencana karir dalam memperkuat motivasi belajar yang telah dimiliki trainer, dengan pertimbangan tersebut diharapkan dapat memberikan gambaran lebih jelas kepada peserta. Pada metodepraktik, peserta berkelompok dan dengan pendampingan trainer mahasiswa bergantian melakukan penyusunan rencana karir dan mensugesti secara bergantian berkaitan dengan temannya. Peserta diajarkan bagaiman acara menyusun karir belajar mereka hingga strategi meraih citacita dengan fokus dan terarah, dengan menggunakan rencana karir yang jelas.

\section{HASIL DAN PEMBAHASAN}

$\begin{array}{lrr}\text { Kegiatan } & \text { Pengabdian } & \text { Kepada } \\ \text { Masyarakat ini } & \text { berkaitan } & \text { erat }\end{array}$ dengan bimbingan karier pada siswa. Bimbingan Karir untuk sekolah menengah harus bisa mengantar setiap pelajar untuk menanggulangi tugas perkembangan menuju perkembangan karier, dan membimbing pelajar kepada kreasi dan prestasi dari seperangkat pilihan dan rencana yang akan di tetapkan. Penekanan penekanan utama dalam aktivitas aktivitas bimbingan karier untuk berbagai individu haruslah didasarkan pada intensitas perencanaan, kesiapan berpartisipasi dalam kehidupan sebagai pribadi yang independent, dan keterarahan individu-individu kepada tujuan. Masalah bimbingan karier di SMA dan SMK:

1. Tidak mampu menganalisis kompetensi pribadi yang dimiliki dengan keterampilan-keterampilan yang diperlukan untuk pilihan-pilihan karier dan mengembangkan rencana-rencana untuk memperkuat keterampilan bila di perlukan

2. Kurang memiliki tanggung jawab dalam perencanaan karier dan konsekuensikonsekuensinya.

3. Tidak siap untuk memenuhi syarat bagi taraf memasuki pekerjaan-pekerjaan dengan mengambil mata pelajaran yang sesuai, dengan pendidikan kooperatif, atau dengan latihan-latihan dalam jabatan.

4. Tidak siap untuk memenuhi syarat bagi pendidikan pasca sekolah lanjutan dengan mengambil mata pelajaran yang diperlukan oleh tipe program dan lembaga yang diinginkan (perguruan tinggi, perdagangan, atau perusahaan)

5. Tidak mampu mengembangkan keterampilan-keterampilan yang berhubungan dengan penggunaan efektif waktu luang.

6. Belum memiliki pilihan perguruan tinggi tertentu, jika setelah tamat tidak masuk dunia kerja

7. Ragu-ragu apakah sekolah atau jurusan yang dipilih sudah tepat atau belum

Permasalahan kematangan karir merupakan permasalahan masa depan remaja sehingga harus dipersiapkan dengan sebaik baiknya, seperti dalam hal merencanakan dan mengambil suatu keputusan karir.

Berdasarkan permasalahan yang dipaparkan di atas. siswa perlu diberikan pelatihan untuk penyusunan rencana karir agar dapat memetakan langkah yang harus mereka ambil. Rencana karir juga dapat membuka wawasan mereka mengenai bakat, minat serta keahlian yang dapat di lakukan kedepannya.

Penyusunan rencana karir untuk memperkuat motivasi belajar siswa SMK Sasmita diharapkan mampu memberikan visi dan semangat baru dalam upaya siswa meraih cita-cita. Penyusunan rencana karir ini adalah dasar yang akan digunakan oleh siswa untuk membentuk mindset, kemampuan berpikir kritis, sistematis dan visioner. Sehingga akan berdampak pada kegiatan belajar yang di lakukannya baik di sekolah maupun di rumah.

Dengan perencanaan karir yang mantab, siswa akan lebih bisa fokus dalam belajar, dapat mengatur diri dengan baik, memiliki tujuan yang pasti, serta akan membuatnya mampu berpikir secara rasional. Siswa akan lebih mengenal dirinya sendiri, potensi yang dimiliki serta upaya yang dapat dilakukan untuk meraih keinginannya dan dapat menikmati prosesnya dengan benar.

Group Discussion yang digunakan sebagai model penyampaian materi dirasa sangat efektif, siswa lebih dapat terbuka dalam menyampaikan keresahannya tentang masa depan dengan suasana yang santai dan terbuka. Seluruh perserta diajak mengutarakan permasalahan untuk kemudian dipecahkan bersama-sama. 
Kebanyakan siswa yang menjadi peserta masih belum memiliki dasar yang kuat dalam perencanaan karir, sehingga motivasi belajar mereka kurang terdongkrak dan menjadi generasi milenial yang mudah mengikuti arus.

Pengisian lembar kerja yang dilakukan individu, lebih banyak menyadarkan siswa tentang apa yang sebenarnya mereka inginkan, siapa mereka, dan apa yang mereka harapkan di masa yang akan datang. Pengisian itu dilakukan secara individu setelah siswa mendapatkan serangkaian materi tentang perencanaan karir. Siswa diajak untuk membuka dirinya dan jujur mengenai keinginan di masa yang akan datang setelah diberikan waktu untuk merenung selama beberapa saat.

Penyusunan Rencana

Karir

mendapatkan hasil yang sangat baik. Siswa lebih peka terhadap diri dan ke mulai dapat mengambil sikap untuk menentukan apasaja yang harus diraih dan ditempuh untuk mewujudkan rencana karirnya tersebut, meski belum terkondidikan dengan baik, mereka mampu memberikan pemaparan akan visi dan karirnya di masa yang akan datang.

\section{PENUTUP}

Hasil kegiatan PKM di SMK Sasmita berjalan dengan lancar. Siswa terlihat fokus dan antusias menyusun rencana karir bagidiri mereka sendiri. Selain itu penyusunan rencana karir dapat memberikan motivasi baru bagi siswa untuk lebih memacu diri dengan meningkatkan soft skill yang dibutuhkan di dunia kerja. Siswa mendapatkan pengalaman dan support untuk menyusun rencana karirnya ke depan sebagai persiapan untuk menghadapi persiapan memasuki dunia kerja dan serta persaingan jika siswa ingin mendalami studi di perguruan tinggi. Siswa mendapatkan ilmu pengetahuan untuk mengmbangkan diri, sehingga bisa digunakan untuk memaksimalkan potensi diri.

\section{DAFTAR PUSTAKA}

Barsah, A., Sudarso, A. P., \& Sunarsi, D. (2020). Analisis Pengaruh Pengajaran dan Sertifikasi Guru terhadap Kompetensi Guru pada
Sekolah Menengah Kejuruan Di Wilayah Parung Panjang Kabupaten Bogor. Journal of Education, Humaniora and Social Sciences (JEHSS), 3(2), 650-657.

Dewa Ketut Sukardi, Pengaantar Pengantar Pelaksanaan Program Bimbingan dan Konseling di Sekolah, RinekaCipta: Jakarta, 2000.

Hermawati, R., Sugiyarti, L., Handayani, R., Sunarsi, D., Alfiah, S., \& Maddinsyah, A. (2020). The Effect of Trilogy Leadership Style and Organization Culture on School Performance: Evidence form Indonesian Senior High School. PalArch's Journal of Archaeology of Egypt/Egyptology, 17(6), 8512-8537.

Pawar, A., Sudan, K., Satini, S., \& Sunarsi, D. (2020). Organizational Servant Leadership. International Journal of Educational Administration, Management, and Leadership, 63-76.

Robert L. Gibson \& Marianne H. Hitchell, Bimbingan dan Konsleing, PustakaPelajar: Yogyakarta, 2011.

Sampurnaningsih, S. R., Andriani, J., Zainudin, Z. A. B. A., \& Sunarsi, D. (2020). The Analysis of Entrepreneurship Character and Entrepreneurship Intention among Students. PalArch's Journal of Archaeology of Egypt/Egyptology, 17(6), 8290-8303.

Santoso, A. B., Husain, B. A., Supiandi, G., Sudarso, A. P., \& Akbar, I. R. Knowledge Sharing Melalui Motivasi Belajar Dan Pelatihan Bahasa Inggris Pada Yayasan Domyadhu Pamulang. Jurnal Pengabdian Dharma Laksana, 3(2), 106-109

Sunarsi, D., Barsah, A., Hastono, H., \& Akbar, I. R. (2020). Pengaruh Harga dan Fasilitas terhadap Minat Sewa Kost yang Berdampak pada Prestasi Belajar Mahasiswa di Yogyakarta. Journal of Education, Humaniora and Social Sciences (JEHSS), 3(2), 601609.

Walgito, Bimo, Bimbingan \& Konseling (Studi dan Karir), ANDI OFFSET: Yogyakarta, 2005. 